\title{
Effect of Different Basal Doses of Boron on Growth and Yield of Urdbean (Vigna mungo L.)
}

\author{
Shakti Om Pathak ${ }^{1 *}$, R. P. Singh ${ }^{2}$, Brijesh Kumar Pandey ${ }^{3}$ and S. K. S. Chandel ${ }^{4}$ \\ ${ }^{1}$ Soil Science \& Agricultural Chemistry, SVPUAT, Meerut, India \\ ${ }^{2}$ Soil Science \& Agricultural Chemistry, Udai Pratap Autonomous College, Varanasi, India \\ ${ }^{3}$ Soil Science \& Agricultural Chemistry, Ghazipur PG College, India \\ ${ }^{4}$ Soil Science \& Agricultural Chemistry, Janta College Bakewar, Etawah, India \\ *Corresponding author
}

\section{A B S T R A C T}

\begin{tabular}{l} 
Ke y w o r d s \\
Boron, Urdbean, \\
Growth attributes, \\
Yield \\
\hline Article Info \\
Accepted: \\
28 April 2020 \\
Available Online: \\
10 May 2020
\end{tabular}

A field experiment was conducted to study the effect of different basal doses of boron on growth \& urdbean during Zaid season 2015 at farm of department Soil Science\& Agricultural Chemistry, Udai Pratap Autonomous College Varanasi. The experiment consisted of six treatments replicated thrice in RBD. The treatment include of $\mathrm{T}_{0}=$ Control (No input), $\mathrm{T}_{1}=\mathrm{RDF}\left(\mathrm{NPK} @ 20: 20: 30 \mathrm{~kg} \mathrm{ha}^{-1}\right), \mathrm{T}_{2}=\left(\mathrm{RDF}+\mathrm{B} @ 0.5 \mathrm{~kg} \mathrm{ha}^{-1}\right), \mathrm{T}_{3}=$ $\left(\mathrm{RDF}+\mathrm{B} @ 1.0 \mathrm{~kg} \mathrm{ha}^{-1}\right), \mathrm{T}_{4}=\left(\mathrm{RDF}+\mathrm{B} @ 2.0 \mathrm{~kg} \mathrm{ha}^{-1}\right), \mathrm{T}_{5}=\left(\mathrm{RDF}+\mathrm{B} @ 2.5 \mathrm{~kg} \mathrm{ha}^{-1}\right)$ Observation related to the effect of treatments on urdbean, were recorded on growth attributes (plant height, no of leaves, no of nodules number of branches) The result revealed that with the application of boron $\left(\mathrm{T}_{4^{-}} \mathrm{RDF}+\mathrm{B} @ 2.0 \mathrm{Kg} \mathrm{ha}^{1}\right)$ the maximum plant height $(28.16 \mathrm{~cm}$ ), no of leaves (48.50) no of branches (15.12)\& no of nodules (15.33) was obtained which was significantly higher from treatment $\mathrm{T}_{0}, \mathrm{~T}_{1}, \& \mathrm{~T}_{5}$. The yield of grain $\left(11.90 \mathrm{qha}^{-1}\right)$ and stover $\left(16.81 \mathrm{qha}^{-1}\right)$ was also higher with the treatment $\mathrm{T}_{4}$.on yield attributes (pods per plant, test weight, grain and stover yield). On the basis of above results be concluded that application of boron is essential for better growth and yield of urdbean as compared to without boron application.

\section{Introduction}

Urdbean [Vigna mungo (L.) Hepper] is one of the important pulse crop grown throughout the country during rainy season although in some instances it is also grown during zaid season. It is a self-pollinated leguminous crop which contain $24 \%$ protein, $60 \%$ carbohydrate, $1.3 \%$ fat, $3.2 \%$ mineral, $0.9 \%$ fiber, calcium, phosphorus, iron and small amount of vitamin B complex. Being a short duration crop, it fits well in various multiple and intercropping systems. After removing pods, its plant may be used as good quality green or dry fodder for animal. Being a leguminous crop, its dual role in providing protein rich seeds and improving soil fertility by adding nitrogen in the soil is well known. Urdbean share 13 percent of total area under pulses and 10per cent of their total production in our country. This crop is extensively grown 
in the states of Madhya Pradesh, Maharashtra, Andhra Pradesh, Tamil Nadu, Uttar Pradesh and Rajasthan. It can be grown on all types of soils ranging from sandy loam to heavy clay except the alkaline and saline soil.

Pulses are the main source of dietary protein particularly for Vegetarians and contribute about 14 per cent of total protein of an average Indian diet. Pulses cover an area of about 23.63 million hectares with an annual production of 14.76 million tones and production of $708 \mathrm{~kg} / \mathrm{ha}$ in our country (GOI, 2014). Production of pulses in the country is far below the requirement to meet even the minimum level per capita consumption. The per capita availability in pulses is decreasing fast from $60.7 \mathrm{~g}$ in 1951 to $47.2 \mathrm{~g}$ in 2014 as against the minimum requirement of $104 \mathrm{~g}$ per capita per day as prescribed by ICMR which is causing malnutrition among the growing people (Commodity India, 2007). Hence, it is necessary for Agriculture scientists to evolve the techniques to boost up pulse production so that protein requirement of increasing population of the country can be meet out.

Boron (B) is an essential micronutrient required for crop growth and yield due to its major role in formation and maintenance of cell wall and cell membrane integrity. Coursetextured acid soils of humid are deficit in boron. Calcareous soils and those with low organic matter content are more prone to B deficiency (Dwivedi et al., 1990 and Niaz et al., 2013). Boron (B) observed in the form of boric acid or borate is an essential micronutrient element for plant growth and development (Loomis and Durst 1992). Boron is retained in soils by adsorption on to minerals and humic particles and by forming insoluble precipitates (Gpblberg and Glaubig, 1985). 4-5 lines related to boron importance for pulse crops.

\section{Materials and Methods}

To study the effect of basal application of boron on growth and productivity of urdbean involves field experiment was conducted during Zaid season of 2015. The soil of experimental site was sandy clay loam in texture, slightly saline and non-alkaline in reaction. Before sowing, initial soil sample was collected randomly from $0-30 \mathrm{~cm}$ depth covering experimental area which was analyzed for various physio-chemical properties. Experiment was laid out in Randomized Block Design with six treatments and three replications. The treatment consisted of $\mathrm{T} 0=$ Control $(\mathrm{No}$ input), T1 = RDF (NPK @ 20:20:30 kg ha ${ }^{-1}$ ), $\mathrm{T} 2=\left(\mathrm{RDF}+\mathrm{B} @ 0.5 \mathrm{~kg} \mathrm{ha}^{-1}\right), \mathrm{T} 3=(\mathrm{RDF}+$ B@1.0 kg ha $\left.{ }^{-1}\right), \mathrm{T} 4=(\mathrm{RDF}+\mathrm{B} @ 2.0 \mathrm{~kg}$ $\left.\mathrm{ha}^{-1}\right), \mathrm{T} 5=\left(\mathrm{RDF}+\mathrm{B} @ 2.5 \mathrm{~kg} \mathrm{ha}^{-1}\right)$. Source of through the N,P, K \& B through the Source of nitrogen phosphorus, potassium and Borax (11\% B).

Urdbean variety i.e. Azad was selected for sowing. The germination test was carried out before sowing. The sowing was done at spacing $30 \mathrm{~cm} \times 5 \mathrm{~cm}$. Gap filling was done wherever it is necessary to maintain the plant population in each plot. Periodical intercultural operations like Weeding and thinning were performed mechanically by hand when required to maintain good cropping condition.

\section{Results and Discussion}

\section{Effect of boron on growth attributes of Urdbean}

Plant height measured at 30 and 60 DAS was significantly affected by different treatments. Among the treatments i.e. $\mathrm{T}_{4}, \mathrm{RDF}+2 \mathrm{~kg} / \mathrm{ha}^{-1}$ boron produce taller plant 24.80 and 28.16 am at 30 and 60 DAS respectively which was significantly higher than $\mathrm{T}_{0}$ and $\mathrm{T}_{5}$. The 
number of leaves counted at 30 and 60 DAS also was differ significantly under different treatments. Maximum number of leaves 43.41 and 48.50 counted at 30 and 60 DAS in $\mathrm{T}_{4}$ were significantly higher than the number of leaves counted in $T_{0}$ and $T_{5}$. Number of branches differs from 7.56 to 13.35 and 9.83 to 15.12 at 30 and 60 DAS respectively. At 30 DAS maximum number of branches 13.35 was found significantly higher than the branches counted in $\mathrm{T}_{6}, \mathrm{~T}_{1}$, and $\mathrm{T}_{5}$ while at 60 DAS significantly higher than $T_{0}, T_{1}, T_{2}$ and $\mathrm{T}_{5}$. Nodules counted at 45 DAS were significantly higher in $\mathrm{T}_{4}$ than the other treatment.

Number of pods per plant was affected remarkably by different treatments. The maximum pods per plant 18.25 significantly higher than the rest of the treatment were found in T4 (RDF + B @ $\left.2.0 \mathrm{~kg} \mathrm{ha}{ }^{1}\right)$. Application of boron increased the vegetative growth in terms of plant height, number of leaves, number of branches and also increased the number of nodules per plant. This might be due to quick availability of boron to crop during the entire growing season. Boron plays an important role in tissue differentiation and carbohydrate metabolism. It is also a constituent of cell membrane and essential for cell division, maintenance of conducting tissue with regulatory effect on other element. It is also necessary for sugar translocation in plant and development of new cell in meristematic tissue. Similar trend finding by Kaisher et al., (2010) observed that boron has significant effect on plant height, number of branches plant ${ }^{-1}$, number of pods plant ${ }^{-1}$, and seed yield of mung bean (Table 1).

Table.1 Effect of basal application of boron on growth attributes of urdbean at different days of intervals

\begin{tabular}{|c|c|c|c|c|c|c|c|}
\hline \multirow[t]{2}{*}{ Treatments } & \multicolumn{2}{|c|}{$\begin{array}{l}\text { Plant height } \\
\text { (cm) } \\
\text { (DAS) }\end{array}$} & \multicolumn{2}{|c|}{$\begin{array}{l}\text { No. of leaves } \\
\quad \text { (DAS) }\end{array}$} & \multicolumn{2}{|c|}{$\begin{array}{c}\text { No. of } \\
\text { branches } \\
\text { (DAS) }\end{array}$} & \multirow{2}{*}{$\begin{array}{c}\begin{array}{c}\text { No. of } \\
\text { nodules } \\
\text { (DAS) }\end{array} \\
45\end{array}$} \\
\hline & 30 & 60 & 30 & 60 & 30 & 60 & \\
\hline$T_{0}=$ Control & 17.45 & 22.33 & 33.83 & 40.16 & 7.56 & 9.83 & 6.33 \\
\hline 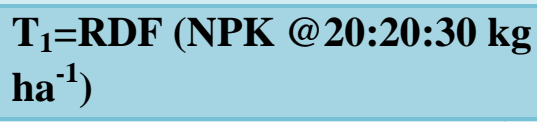 & 22.20 & 26.58 & 37.75 & 43.50 & 8.45 & 11.54 & 8.33 \\
\hline$T_{2}=\left(R D F+B @ 0.5 \mathrm{~kg} \mathrm{ha}^{-1}\right)$ & 23.20 & 27.50 & 40.33 & 43.58 & 10.12 & 12.23 & 11 \\
\hline$T_{3}=\left(R D F+B @ 1.0 \mathrm{~kg} \mathrm{ha}^{-1}\right)$ & 23.45 & 28.13 & 42.41 & 48.00 & 11.89 & 13.98 & 12.66 \\
\hline$T_{4}=\left(R D F+B @ 2.0 \mathrm{~kg} \mathrm{ha}^{-1}\right)$ & 24.80 & 28.16 & 43.41 & 48.50 & 13.35 & 15.12 & 15.33 \\
\hline$T_{5}=\left(R D F+B @ 2.5 \mathrm{~kg} \mathrm{ha}^{-1}\right)$ & 16.83 & 21.50 & 31.83 & 38.08 & 7.10 & 9.23 & 5 \\
\hline SEm \pm & 1.25 & 1.23 & 2.94 & 1.84 & 1.00 & 0.72 & 0.59 \\
\hline CD (0.05) & 2.79 & 3.64 & 6.55 & 4.10 & 2.22 & 1.60 & 1.31 \\
\hline
\end{tabular}


Table.2 Effect of basal application of boron on yield and yield attributes of urdbean

\begin{tabular}{|c|c|c|c|c|}
\hline Treatments & $\begin{array}{l}\text { No. of pods } \\
\text { plant }^{-1}\end{array}$ & $\begin{array}{c}\text { Test weight } \\
\text { (g) }\end{array}$ & Grain yield $\left(\mathrm{q} \mathrm{ha}^{-1}\right)$ & $\begin{array}{l}\text { Stover yield } \\
\quad\left(\mathbf{q} \mathbf{h a}^{-1}\right)\end{array}$ \\
\hline$T_{0}=$ Control & 10.10 & 33.10 & 4.78 & 8.9 \\
\hline $\begin{array}{l}T_{1}=\text { RDF (NPK } \\
\left.@ 20: 20: 30 \mathrm{~kg} \mathrm{ha}^{-1}\right)\end{array}$ & 11.62 & 36.66 & 5.90 & 9.96 \\
\hline $\begin{array}{l}T_{2}=(R D F+B @ 0.5 \\
\left.\mathrm{kg} \mathrm{ha}^{-1}\right)\end{array}$ & 13.25 & 40.15 & 7.55 & 12.16 \\
\hline $\begin{array}{l}T_{3}=(R D F+B @ 1.0 \\
\left.\mathrm{kg} \mathrm{ha}^{-1}\right)\end{array}$ & 16.10 & 44.25 & 9.63 & 14.76 \\
\hline $\begin{array}{l}T_{4}=(R D F+B @ 2.0 \mathrm{~kg} \\
\left.\mathrm{ha}^{-1}\right)\end{array}$ & 18.25 & 48.10 & 11.90 & 16.81 \\
\hline $\begin{array}{l}T_{5}=(\text { RDF +B @ } 2.5 \mathrm{~kg} \\
\left.\mathrm{ha}^{-1}\right)\end{array}$ & 8.10 & 28.88 & 3.11 & 7.08 \\
\hline SEm \pm & 0.92 & 2.05 & 0.09 & 0.07 \\
\hline CD (0.05) & 2.05 & 4.57 & 0.21 & 0.16 \\
\hline
\end{tabular}

Effect of boron on yield attributes and yield of urdbean

Among all the treatments $\mathrm{T}_{4} \mathrm{RDF}+2 \mathrm{~kg} / \mathrm{ha}^{-1}$ boron significantly produce higher yield attributes, number of pods per plant (18.25), grain yield $\left(11.90 \mathrm{q} \mathrm{ha}^{-1}\right)$ and stover yield $\left(16.81 \mathrm{q} \mathrm{ha}^{-1}\right)$ which was significantly higher from all the treatment (Table 2).

Basal application of boron@ $2 \mathrm{~kg} / \mathrm{ha}^{-1}$ before sowing was found to enhance yield and yield attributes of urdbean significantly over other treatments. This are results is similar to finding the reported by (Sakal et al., 1988) who reported that application of $2 \mathrm{~kg} \mathrm{ha}^{-1}$ boron resulted an increase in grain yield of black gram and chickpea by 33 and 38 percent, respectively. The beneficial effect of boron on yield attributes may be due to flower development pollen grain formation, pollen viability, pollen tube growth for proper pollination and seed development on reported by (Ram et al., 2017). Naveen and stalin (2013) found a residual effect of $\mathrm{ZnSO}_{4}$ and borax application@50 and $10 \mathrm{Kg} \mathrm{ha}{ }^{-1}$ respectively on black gram. The same treatment also influenced the yield attributes viz., the highest number of pods plant ${ }^{-1}$ and 100 seed weight.

It can be concluded from all the above results that application of boron with recommended dose of fertilizer will produce a significant higher yield with all other growth \& yield attributing characters but in the same finding also revealed that a much higher dose of boron was unable to produce good yield.

\section{References}

Dwivedi, B.S., Ram, M., Singh, B.P., Das, M. and Prasad, R.N. (1990). Differential response of crop to boron fertilizer in 
acid alfisols. Indian Journal of Agricultural Science, 60, 122-127

Goldberg, S., and R.A. Glaubig. (1985). Boron adsorption on aluminum and iron oxide minerals. Soil Science Society of American Journal, 49:1374-1379.

Gupta, Umesh, C., Srivastava, Prakash, C. and Gupta, Subhas, C. (2011) Role of micronutrients: boron and molybdenum in crops and in human health and nutrition. Current Nutrition and Food Science, 7, 126-136.

Kaisher. M. S., M.T Rahman, M. H. A. Amin, A. S. M. Amanullah and A. S. M. Ahsanullah. (2010). Effects of sulphur and boron on the seed yield and protein content of mungbean. Bangladesh Research Publication Journal, 3(4): 1181-1186.

Loomis W D and Durst RW (1992). Chemistry and biology of boron.Biofactor, 3 229-239.

M. Naveen Saviour and P. Stalin (2013). Influence of Zinc and Boron in Residual Blackgram Productivity, Indian Journal of Science and Technology, 0974-6846.

Naveen M. and Stalin P. (2013). Influence of Zinc and Boron in Residual Blackgram Productivity. Indian Journal of Science and Technology, 6 (8):0974-6846

Niaz, A., Ahmed, W., Zia, M.H. and Malhi, S.S. (2013). Relationship of soil extractable and fertilizer boron to some soil properties, crop yields and total boron in cotton and wheat plants on selected soil of Punjab, Pakistan. Journal of Plant Nutrition, 36, 343-356.

Pandey, N. and Gupta, B. (2012). The impact of foliar boron sprays on reproductive biology and seed quality of black gram. Plant Nutrition and Stress Physiology Laboratory, Department of Botany. University of Lucknow.

Ram, Chena, Singh, Devendra and Jat, Bhanwar Lal (2017). Effects of different phosphorus levels and frequency of boron levels on growth and yield of greengram. Adv. Res. J. Crop Improv, 8(1): 49-61.

Sakal, R., Sinha, R. B., Singh, A. P. (1988). Effect of B application on Black gram and Chickpea, Production in Calcareous soil. Fertilizer News. 33: 27-30.

Saviour M. N. and Stalin P. (2013). Influence of Zinc and Boron in Residual Blackgram Productivity. Indian Journal of Science and Technology, 6 (8).

\section{How to cite this article:}

Shakti Om Pathak, R. P. Singh, Brijesh Kumar Pandey and Chandel, S. K. S. 2020. Effect of Different Basal Doses of Boron on Growth and Yield of Urdbean (Vigna mungo L.). Int.J.Curr.Microbiol.App.Sci. 9(05): 3428-3432. doi: https://doi.org/10.20546/ijcmas.2020.905.407 